Zsolt Boda

\title{
On The Ethics of Development in the Age of Globalization
}

Denis Goulet, the founding father of the interdisciplinary field of development ethics argued that "In ever-new and ever-changing settings, development poses ancient philosophical questions: what is the good life (...), what are the foundation of life in society, and what stance should human groups adopt toward nature? 'Development' provides one particular answer to these questions. (...) What is needed is a critical questioning of the very nature of development and of its declared goals (...)" (Goulet, 1995: ix). Questions about good life have indeed been an age-old concern for humanity, however, development in a modern sense is a much newer project and from the very beginning its "particular answer" has been appropriated by economists. Wolfgang Sachs refers to a 1949 speech by American President Harry S. Truman as a symbolic starting point of the modern development discourse in which Truman set a new political goal: helping to develop the 'underdeveloped' regions of the world (Sachs, 1997). The project of development as an international endeavour was born; and its very nature as well as its goals were defined in economic terms, as for Truman development clearly meant material growth.

One can argue that the dominance of economics in the development discourse was a phenomenon of the early decades of developmentalism and that since than the concept of development has been reinterpreted as a complex, multi-faceted one, including social, economic, cultural, political and environmental aspects. There is truth in that view. In fact, prominent and critically-minded economists, like Paul Streeten, Gunnar Myrdal, Amartya Sen and Joseph Stiglitz, to name just a few, have played an important role to relativize the importance of the economic domain in development. Decades of ever-broadening development discourse have brought about many critical ideas, both theoretical, normative and practical enquiries about the ends, the means and the process of development. The ideas put forth by Denis Goulet and others already in the 1960s and 1970s should be evident to everyone dealing with the topic: development is a complex and contested concept with essentially normative nature. It should be also clear that development is not only a problem of the 'underdeveloped' - the global ecological crisis is actually a produce of 'overdevelopment'. Making our societies better in a deep sense is an urging challenge all over the world, and meeting that challenge requires locally embedded, but globally feasible approaches.

However, this paper argues that there is a considerable mismatch between development ideas and the dominant paradigm of development as expressed both by foundational international documents and development practice - more particularly, I will refer to the Millenium Development Goals (2000) of the United Nations as the most important development document of the $21^{\text {st }}$ century. Despite the sophistication of development studies, political action and development practice is still under the influence of old ideas and institutional 
constraints. The task of development ethics is as defined by Goulet is still relevant: we should keep inquiring about the goals and very nature of development.

This chapter focuses on three interrelated problems that embody the essential contradictions of the mainstream development ideas in the globalization age. First, development is still mostly defined in materialistic terms, and, as such, it is largely under the influence of mainstream economic considerations. Development is about achieving economic success in the global economic system. Second, development has remained the problem of 'poor countries' - the 'developed' nations are apparently reluctant to face the development crisis they have caused, although ecological problems made it truly global. Third, although the development project was born as an international one, it has failed to truly unfold as such despite the advent of the 'age of globalization'. Paradoxically, globalization brought about ideas on limited global solidarity and international cooperation, except the field of neoliberal economic policy.

\section{Materialistic development}

Development in the beginning was almost exclusively defined in economic terms: the problem was defined as how to get the economy grow in order to increase per capita income, measured in GDP and similar indicators (see Rostow, 1959). However, even Rostow contextualized economic growth in the modernization processes of the society; and already in 1962 the basic document of the first UN Development Decade stressed that development is more than growth: it should aim at improving the quality of life of people (UN, 1962).

But it is not self-evident that GDP growth cannot be used as a proxy for increasing quality of life. The high number of people in need (starvation in the 1960s struck almost every fourth person in the world) could alone justify a focus on material goods. The argument sounds plausible that the urgency of unmet human needs justifies the priority on economic matters fulfilling other development objectives will then follow. Another way economic reasoning tries to maintain control over development issues is to argue that material resources are only means that can be used to promote the politically desirable development objectives. That is, GDP growth is maybe not the same as quality of life improvement, but it can be used for that purpose as a neutral instrument - economics as such is value-neutral and does not force any value choice upon decision-makers (Gasper, 2004; Wilber, 2010).

The past decades have accumulated a large amount of empirical evidences and analytical arguments against those views. For instance Paul Streeten argued that even high economic growth did not necessary improve the situation of the poorest people in the society (Streeten $\&$ Burki, 1978). Meeting basic needs necessitates targeted policies which are not dependent on the level of economic growth. But the most forceful critique of economic reductionism came from Nobel laurate Amartya Sen whose oeuvre in large part focuses on issues of development: what is it and how can it be achieved. Sen makes strong arguments against the idea that development problems stems from a lack of economic resources.

First, his studies on famines convincingly demonstrate that hunger is not simply caused by a shortage of food (as material goods) rather it is the result of an interplay between the lack of 
rights or entitlements to the resources and effective public action addressing the problem (Dreze, Sen, \& others, 1991; Sen, 1981). Natural disasters or wars can indeed create food shortages locally and temporarily; but it is very seldom that a whole country be struck by the lack of food. The history of famines shows that elite groups or the power centre generally dispose of enough resources, but they do not share them with those in needs - in some cases (e.g. the Ukrainian famine of the 1930s) political decisions and action are even causing the famine to break out. That is, hunger is not a phenomenon of absolute material shortage but that of unequal access to the resources. If people have the right to material resources, and that right is effectively enforced, they do not need to starve.

However, what can make the elite enforce rights that actually curtail their own privileges? This happens sometime as 'enlightened elites' may link their welfare to the general welfare of their society; however, typically right enforcement needs a political system based on the rule of law and accountability, that is, some form of democracy (Acemoglu \& Robinson, 2012). Amartya Sen is also arguing that democracy prevents famines because free press and public opinion puts the government under pressure to act in an emergency situation (Sen, 1981). The most devastating famines happened in countries under dictatorial rule. These arguments point to the importance of both effectively enforced normative concepts (rights, entitlements) and institutional-political settings in promoting development before the problem of absolute resource scarcity.

Second, Amartya Sen proves that per capita GDP is not a good measure of development; moreover, that GDP growth is neither a necessary, nor a sufficient condition of it. This argument presupposes that the notion of development be dissociated from that of per capita income. For Sen development is related to the quality of life which is best measured in human capabilities: what people can be and do, what is the degree of freedom they enjoy when making choices in life (Sen \& others, 1988). This is a clear normative position and echoes what Goulet said about development: that it should be about good life. Sen first used life expectancy as a measure of quality of life. Although he admits that it looks a rather quantitative measure, but it is in fact a complex indicator of the living conditions in a society, including inequalities, access to health and education, the level of crime and so on (Sen \& others, 1988). While life expectancy is a good composite measure of many aspects of life quality, a longer life is also to be valued for itself: reaching a certain age is a condition of developing and nurturing capabilities.

What is the relationship between GDP and quality of life/life expectancy? The question seems to be an easy one: people in richer countries enjoy longer lives. However, measure of level and measures of change should not be conflated; and correlation does not mean causation. It might be that in the actual state of affairs richer countries have higher life expectancy, but does it follow that increasing GDP is the best way to increase longevity in a given country? In fact, throughout the 20th century in Great Britain changes in per capita GDP and life expectancy has been opposite to each other (Sen, 1998). Sen also points to the many deviant cases: rich countries with relatively low and poor countries with relatively high life expectancy (Sen \& others, 1988). Following Sen's ideas Anand and Ravallion (1993) empirically prove that GDP growth leads to increasing life expectancy only if the disposable income of the poorest people is increasing and/or income is redistributed through effective 
public services reaching out to the poor. These conditions are not self-evidently fulfilled even in case of high GDP growth rate. The market does not necessarily reward the poorest usually the less productive and less organized - segment of the society, and elites are not necessary eager to spend on public services and social policies. Anand and Ravallion's conditions actually requires specific political decisions, policies and institutional arrangements.

Following these findings and arguments we must say that while increasing income may lead to improving quality of life, this effect is conditional. On the other hand quality of life can be improved via community supported programs even at a low income level, as the example of State of Kerala - one of Sen' recurring references - suggest. The capability set of people can be meaningfully extended, poverty reduced and basic needs met at low income level as well. The capability approach, while having deep philosophical and ethical roots, has also clear policy implications. Let us mention that Denis Goulet's ideas often overlap with Sen's, as both of them define development in terms of growing freedoms of the individual.

It is not my intention to provide a detailed presentation of the oeuvre of Sen or the debates concerning the meaning of development that have characterized the decades of development discourse. The above arguments are meant to illustrate the point that economic reductionism has been under scrutiny for a long time; and that criticisms have not only been of ethical or philosophical nature, but rooted in empirical evidences and advanced by economists. We cannot say that those ideas have not had any effect on policies. Sen himself contributed to the elaboration of the Human Development Index (HDI) at the UNDP which combines life expectancy and an education index with per capita income and which represents a somewhat alternative measure of development compared to GDP. But we cannot say either that economic reductionism would be outdated. Both economists, development experts and politicians still widely use it and refer to GDP levels as the most important development indicator (Peet \& Hartwick, 2015). While the appropriateness of GDP to measure welfare was already questioned in the 1970s (Nordhaus \& Tobin, 1972) and later several times (Daly, Cobb, \& Cobb, 1994), recently Nobel laurate economists had to argue again against it - with no much success (J. E. Stiglitz, Sen, \& Fitoussi, 2010).

More particularly, development objectives have also been set along economic and material terms. For instance the Millenium Development Goals, using an old and somewhat arbitrary threshold (see on this Wade, 2004), defines poverty as earning less than USD 1 per day. That is, poverty is first of all about income, it is not about, say, capabilities. ${ }^{1}$ This is not a theoretical problem. The MDGs set the objective to halve poverty so defined, and $2015 \mathrm{UN}$ Millenium Develoment Goals Report proudly announced that the goal was reached. Maybe so. However, the target could be achieved simply by increasing the number of people who live from the market and have financial revenues - as opposed to people living in autarchy or receiving in-kind support from their families or communities (Vandemoortele, 2011). Extending markets and financial transactions is certainly part of the neoliberal agenda of today's economic globalization. Whether this leads to poverty reduction and if so, how much,

\footnotetext{
${ }^{1}$ To do justice to the MDGs: meeting basic needs like eradicating hunger is also an objective, just like increasing school enrollment, improving gender inequalities etc. Reducing income poverty is not the only development goal, but it is the first one.
} 
is difficult to see, and not only for the well-known problems of statistical measures (see on this Vandemoortele, 2011; Wade, 2004). And whether the reduction of income poverty - if so - leads to increasing capabilities is still to be proven.

Summing up, despite decades of both normative and empirical assessments of the limitations of the economic approach to development, the economic reductionism is still influential. Vandermoortele (2011) argues that one of the original intentions of the Millenium Development Goals was exactly to broaden the development discourse which was dominated by economic consideration, and include other aspects and dimensions of development, but they failed to do so. Instead, MDGs themselves reflect the mainstream paradigm based on trade and financial liberalization, and the challenge of development largely remained framed along materialistic and economic terms. Despite decades of reflections on the meaning of development, the most important development policy document if the $21^{\text {st }}$ century still largely reflects rather old ideas and mainstream economic recipes.

\section{Whose development?}

None of the MDGs address the rich countries - looks like development is an issue for poor countries only, whose task is to imitate the model of rich countries. As if we were still in the paradigm of Harry S. Truman who almost 70 years ago set the goal of helping underdeveloped regions of the world.

Again, it should be clear since the early 1970s that development as we know it is not good in a deep sense, because it is destroying the Earth and the natural environment upon which all life depends. The Report to the Club of Rome projected an ecological and disaster to the beginning of the $21^{\text {st }}$ century, were the actual trends of resource depletion and pollution continued (D. H. Meadows, 1972). Thirty years later the prospects are not better, in some sense even worse, as anthropogenic climate change has imposed itself as the major menace humanity has ever faced (D. Meadows, Randers, \& Meadows, 2004). The scientific consensus now is that climate change is happening; that it is caused by humanity; and its consequences will be dramatic in the not too distant future. It is also clear that global warming as well as many other forms of environmental degradation have been caused by two centuries of extensive fossil fuel use, deforestation for agricultural purposes, mining, pollution by modern industries and similar activities - the core of modern development that poor countries are supposed to imitate. Rich countries not only bear the historical responsibility for today's global ecological problems, but even today their per capita resource use and pollution surpass by several factor those of the developing countries. This is a problem of global justice that should first and foremost be repaired on the side of the rich countries (Singer, 2004).

There is hardly any new in the above said. In 1987 Our Common Future, the report of the Brundtland Commission made a clear case on both the environmental unsustainability of the mainstream development paradigm and the resulting serious global justice problem (Brundtland et al., 1987). At the same time, the report is a political document and such, burdened with some compromises. For instance, while the report provides a forceful critique of the mainstream development it also stresses the importance of global economic cooperation 
in the form of trade liberalization. Bernstein argue that the hidden (or not so hidden) neoliberal agenda of the Brundtland Report dominated then the 1992 Earth Summit of Rio de Janeiro and in general, the environment and development discourse of the 1990s (Bernstein, 2002). The term 'sustainable development', popularized by the Brundtland Report, has become a mandatory reference in the development discourse, but this has not meant the reappraisal of the development model of globalization. On the contrary. The documents of Rio, Johannesburg (2002) or that of the MDGs make parallel reference to liberal globalization and the need of sustainable development - voiding the latter of its potentially radical content. Because we have good reasons to believe that economic globalization in its present form is by no means compatible with ecologically sustainable development (Daly \& Farley, 2011).

Let us mention another problem that challenges the development model of the rich countries: that of growing inequality. Recently the work of Thomas Piketty pointed to the fact that the distribution of both income and wealth are becoming increasingly unequal all around the world (Piketty, 2014). ${ }^{2}$ Piketty argues that the main cause of this phenomenon lies in the inherent logic of global capitalism and capital accumulation. Growing inequality is not only a problem from an egalitarian normative perspective - it is actually at the root of a number of political and social problems. Piketty is warning that increasing inequality may create a hierarchical society where mobility is severely constrained, and this can undermine both the merit-based normative justification of the social order and the actual performance of the society, as talented, but less resourceful people will face reduced opportunities in life. Inequality is undermining democracy, as people have increasingly differentiated access to decisions and decision makers, and the will of the wealthy will prevail (Gilens \& Page, 2014; J. Stiglitz, 2012). Inequality is also eroding social trust towards both other people and the institutions (Uslaner, 2002).

The multiple negative social consequences of inequality have been thoroughly presented by Wilkinson and Pickett (2010). They argue that inequality causes or worsens a number of social problems, like reduced life expectancy, mental illness, obesity, homicide rate, incarceration rate, poor school performance, teenage birth, infant mortality, low social mobility. They actually find that even per capita environmental pollution is positively related to simple measures of income inequality. Their analysis not only describes the positive associations between inequality and the social ills, but, relying on previous empirical studies, reconstructs the mechanisms through which those social problems are produced. We cannot present here in detail the arguments of their influential work. But the implication is quite straightforward: if inequality continues to increase, as predicted by Piketty and others, this will lead to a deterioration of the quality of life in the most developed countries as well. Conversely, if we seek to improve the quality of life, inequality should be reduced. This is not an argument in favour of radical egalitarianism. But, as Wilkinson and Pickett put it, instead of treating social ills through spending on police, prisons, doctors, social workers,

\footnotetext{
${ }^{2}$ I am referring here to inequalities inside nations. The question about global inequalities is a bit more complicated: on some accounts they have been shrinking in the past decades (mostly due to the growing income in China and some other developing countries), but according to other measures they have been widening (Milanovic, 2011; Wade, 2004).
} 
psychologists and so, rich countries should devote some effort to reduce income differences between people (Wilkinson \& Pickett, 2010).

Development should not be only a task for poor countries. Rich countries are not at the 'end of history' either: they can and should increase the quality of life of their people and respond to new challenges, like the one of growing inequality. However, most importantly they need to address at last a fundamental problem stemming from their way of development: the ecological crisis.

The 2015 Sustainable Development Goals set by the UN as a follow-up of the MDGs (which were defined for the period of 2000-2015) reflect a move towards the approach advocated here, as they include targets for the rich countries as well. ${ }^{3}$ The SDGs speak parallel of poverty reduction and sustainable consumption, making clear that achieving sustainable development sets targets for every nation. However, it is to be seen whether the SDGs indeed represent a new age of development discourse and - more importantly - development practice.

\section{Global cooperation and global justice}

Although Harry S. Truman presented development as a common endeavour of rich countries to help the poor ones, for many years development was rather seen as a task before the national economies and economic policies. This approach is exemplified by the famous 'stages of economic growth' model which describes how factors of production, internal capital accumulation and growing demand can create the conditions of the much need economic take-off in developing countries (Rostow, 1959). The model is an idealtypical presentation of the development paths of the Western countries, however, the international context was largely neglected in it - as if countries were stand-alone economic units aiming at maximizing income.

The work of Raúl Prebitsch, Immanuel Wallerstein and others pointed to the role of international economic relations, or more generally the global economic system in influencing individual countries' development opportunities (see Love, 1980). Prebisch argued that trade between 'developed' and 'underdeveloped' countries was fundamentally unequal, a thesis than led to two possible conclusions: developing countries should either minimize the economic relations with rich nations or promote new rules for the international economy ones that reflect the developing countries' needs. Import-substituting economic policies adopted by Latin-American countries were the realization of the former, while for instance the formation of the UN Conference on Trade and Development (UNCTAD), of which Prebisch was the first secretary-general, in 1964 put in practice the latter. Throughout the 1960s UNCTAD argued for international redistribution (in the forms of substantial aid, debt reduction and technology transfer), preferential treatment measures in trade as well as schemes aiming at stabilizing export revenues in developing countries. These claims were directly translated into the document of the New International Economic Order (NIEO) - a

\footnotetext{
${ }^{3}$ See at https://sustainabledevelopment.un.org/?menu=1300.
} 
resolution passed by the UN General Assembly in 1974 urging for the reform of international economic relations.

It is quite common to interpret the NIEO as an embodiment of some kind of global justice (see Bhagwati, 1977) - a claim for a more equitable international economic order, where the unequal distribution of revenues and the inherent inequalities are at least partly counterbalanced. Of course, UNCTAD and NIEO were not able to reform the global economy, but some practical changes still happened. The trading regime (GATT) accepted the Generalized System of Preferences that allowed providing non-reciprocal preferential measures to developing countries. In the Lomé Convention the European Communities set up the STABEX mechanism which offered an interest-free loan for countries of which the export earnings of a group of raw and semi-processed goods fall significantly under the average of previous years. 4

Another example expressing the spirit of global justice is the concept of the Common Heritage of Mankind, adopted in 1970 by the UN General Assembly. According to the UN resolution, the deep sea bed is the common heritage of mankind, and it must be exploited for the mankind as a whole, taking into particular consideration the interests and needs of developing countries. Obviously the concept embodies moral commitment towards a more equitable international order and international justice (see Anand, 2004).

I would argue that the 'justice as fairness' concept and the difference principle of John Rawls are useful conceptual tools for interpreting the normative content of the NIEO, preferential trade measures or the Common Heritage of Mankind. ${ }^{5}$ The difference principle demands the evaluation and comparison of entire institutional structures from the point of view of the worst-off persons, or, in the case of the international economic system, the worst-off countries. International institutions and rules are to be arranged so that they are to the greatest benefit of the least advantaged countries; or at least that they are to a greater benefit of the least advantaged countries than of the developed ones.

The concept of justice as fairness has an enormous normative power. It should be one of the guiding principles for international regimes, the complex institutional design of global governance. The development discourse, and to some extent the institutional practice, of the 1960 s and 1970s reflected the idea of global justice and solidarity.

However, the decades of developmentalism came to an end by the late 1980s, early 1990s with the advent of the age of globalisation (Kalb, 2005). The once widespread discourse on the responsibility of the rich countries to help the poor ones, the ideas on international solidarity, the proposals on the Common Heritage of Mankind or the New International Economic Order reflecting the belief in a more equitable world have all faded away (see Anand, 2004). It is not to idealize to 1960 s o the 1970 s - real development was a scarce good than as well, but at least the development discourse of the age provided a powerful frame to

\footnotetext{
${ }^{4}$ Barber and Dickson (1995) argue that the motivation for setting up the European Community's compensatory funds was not informed by the desire to create a more equitable world trading system. Nevertheless, in practice they contributed to some income redistribution in an international scale, and they were actually asked for by developing countries in previous UNCTAD conferences.

${ }^{5}$ John Rawls was reluctant to apply the difference principle to international relations. However, both Beitz (1979) and Boxill (1987) argue that this is a meaningful approach.
} 
think about the responsibilities of the rich, the needs of the poor and the prospects of a better world. The 1980s brought about important political, economic and ideational changes that had their effects on how we think of the problem of development now. People in poor countries have found themselves in the era of unleashed neoliberal globalization with strongly institutionalized free trade rules and corporate interests. The discourse of global justice was substituted by that of structural adjustment, competitiveness and "the market knows better".

From the development perspective the age of globalisation means paradoxically a diminished commitment towards global cooperation - except in the domain of neoliberal economic policies. The World Trade Organisation, established in 1994, has become the strongest institutional element in the architecture of global governance, an international organisation able to allow sanctions on non-complying parties, with the primary objective of promoting liberal trade policies. While the Doha Round of trade negotiations, starting in 2001 was announced as a 'Development Round', its failure clearly shows a lack of commitment to take developing country needs seriously. The role that the International Monetary Fund and the World Bank played in promoting the so-called 'Washington Consensus' in developing countries is also well known (Van Waeyenberge, 2006). In sum, the development model of the globalization era implies that (1) individual countries (2) should integrate their economies into the liberal global economic system (3) and make their institutional and physical infrastructure compatible with the logic of operation of globalization. International cooperation is mostly restricted to institutionalising neoliberal policies; aid and any other forms of solidarity are of a minor importance and only of supplementary nature. As Denis Goulet put it: "The driving idea behind globalization is free-market capitalism - the more you let market forces rule and the more you open your economy to free trade and competition the more efficient and flourishing your economy will be" (Goulet, 2004: 3).

The political goal of liberalizing economic relations has been repeatedly stressed in international development documents, like the Rio Declaration (1992), the Millenium Declaration (2000) and the Johannesburg Declaration (2002). At the same time the idea of global justice has been omitted from the new development discourse. While the concept of sustainable development, popularized by the Report of the Brundtland Commission (Our Common Future, 1987) was defined along both inter- and intragenerational justice, the Rio Declaration mentions only "shared, but differentiated" responsibility in managing the global commons.

The Millenium Declaration and the Millenium Development Goals (MDGs) that are supposed to herald the new development era are usually interpreted as 'neoliberalism with a human face' (Gore, 2010; Vandemoortele, 2011). It is not to make a final account of the MDGs programme here. Addressing basic needs in the least developed countries; reducing debts; increasing aids are certainly objectives to agree with. ${ }^{6}$ But the MDG-paradigm failed to deliver a coherent global development model - countries are stand-alone units with problems to be addressed (Gore, 2010). Solidarity is interpreted at the level of donor countries, not at the level of the global economic system.

\footnotetext{
${ }^{6}$ While the UN is mostly positive concerning the realization of MDGs, independent evaluations are more sceptical. For instance Friedman (2013) argues that while development indicators have been improving in the past two decades, the effect of MDGs cannot be convincingly demonstrated.
} 
I would argue that the neoliberal model that became the mainstream development paradigm in the 1980s is still dominant in international documents or the discourses of influential global institutions: countries are seen to be successful as long as they are integrated into the flows of economic globalization. True, the 'great globalization debate' (Kalb, 2005) that has been going on since the beginning of the 1990s between globalization critics and globalization supporters has brought up many legitimate arguments against the uncritical application of the neoliberal policies of the 'Washington Consensus'. The global economic crisis starting in 2007 put another deep dent into the neoliberal paradigm. However, the 'post-Washington Consensus' has not been able to take shape as its elements are not clear enough and the ideas of neoliberal globalization are still largely defining development policy discourse and practice (Sheppard \& Leitner, 2010; Van Waeyenberge, 2006). Paradoxically, the 2007 crisis reinvigorated neoliberal institutions like the IMF or the World Bank. Beforehand the IMF struggled with finding a new role in global governance as financial markets provided resources to countries with better conditions than the IMF which was gradually marginalized by globalization itself. But this changed when the G-20 leaders agreed to ensure that the Bretton Woods institutions would have as much as $\$ 1$ trillion in additional resources to help countries in financial problems (Birdsall \& Fukuyama, 2011).

The institutional design of global governance and global cooperation still reflects the neoliberal globalization paradigm. Indeed, there are some new developments, but they do not necessarily point towards global solidarity and global environmental justice, rather herald a coming era of increased regional competition and express the concerns of rich countries about their strengthening rivals. The planned Transatlantic Trade and Investment Partnership (TTIP) between the US and the EU, or the Trans-Pacific Partnership between the US, Japan and other Asian countries (excluding China) deserve attention in this respect. On one hand these agreements seek to institutionalize corporate-led globalization as they ensure special rights for corporations, minimizing the possibility of regulating investment and trade by governments. However, they represent a shift from neoliberal policies on the global level, on the other, as they are about creating regional trading blocks and bringing together the rich countries against the rising big rivals, like China, India or Brazil. In a sense these agreements show the ugliest face of corporate globalization (Boda, 2015).

\section{The ethics of development}

Development is, or should be, about making our life and our world better. As such, it is essentially both a normative and a pragmatic endeavour, involving values and principles, choices about desirable ends and legitimate means. The term 'ethics of development' is almost a tautology, because any serious discussion about development must involve ethics.

Development is a collective endeavour: it is about the objectives, norms and strategies to be followed by a group of people; a society; or, on a final account, by humanity as such. This raises specific problems concerning the procedures of decision making and implementation. Denis Goulet has been particularly sensitive to these issues and stressed that the ethics of development must deal with three basic problems: what are the objective of development; what are the means chosen to achieve those objectives; and what are the procedures through 
which specific development outcomes will be produced (Goulet, 1995). Goulet believed in the potential of participatory decision making and argued for new forms of participation in the development process (Goulet, 1989).

The procedural element in the development process is an especially important one, because development is embedded into a system of institutional constraints and power relations (see Sachs, 1997). From the very beginning development has been defined as a hierarchical, a topdown project, an asymmetrical relationship between those already developed and those in need of development; or between the developers (elites, experts etc.) and the subjects of development (people in poor countries). Who is making decisions on whose behalf? What is the degree of freedom of people influencing decisions and development outcomes directly affecting their lives? These and similar questions are of a paramount importance if we seek to assess the ethicality of the development project.

However, the ambition of this chapter could not be presenting the rich field and the many challenges of development ethics. More particularly, it could not deal with the procedural part of the development project. Its aim was to point to some basic contradictions in today's development discourse and practice - ones that haunt and jeopardize the development project from its very beginnings. An essential problem of development is that it has been taken over by economists who have defined its objective and nature in economic terms. This economic bias reduces the richness of the development challenge and actually may cause a failure on its own terms: economic growth alone has been unable to secure basic needs and improve quality of life. Furthermore, economic growth and materialistic development are at the very root of today's global ecological crisis. Rich countries should face their responsibility in causing the ultimate failure of modernity and reinvent their development model. They should also face their global responsibility and the global justice claims today's development issues raise. Sustainable development institutionalising both intra- and intergenerational justice could be achieved only through global cooperation based on solidarity and fairness.

These arguments support Denis Goulet's theses on the multidimensional character of development and the need for complex institutional arrangements to serve the objectives of development. He argued that development must be sustainable in economic, political, social, cultural and ecological terms (Goulet, 1995). Development should rely on an economic system which is able to generate the necessary material resources for people within the limits of ecological sustainability. Market as an economic mechanism is a useful tool, however, Goulet argued that we should avoid that markets rule the society (Goulet, 2004). Markets create inequalities and polarize societies, therefore they must be regulated and complemented by redistributive systems. The viability of institutional arrangements on a final account depends on the sustainability of political processes: how decisions are made, power is distributed and legitimacy ensured. Goulet believed in the potential of local development, that is, bringing the development project the closest possible to communities and people and organize social life at the lowest level - this is sometimes called subsidiarity. However, he was also convinced that the state level cannot be eliminated, otherwise big corporation would take over the organization of social life (Goulet, 2004). And he was also repeatedly arguing that development for the humanity cannot be achieved without global cooperation based on global solidarity. 
Goulet was aware of the value conflicts that development generates. He distinguished three basic value conflicts (Goulet, 2004). The first is about the content of good life. For instance, what is the importance of material values compared to other cultural and ethical ones in the organization of social life? The second bears on the foundation of justice in a polity. What conception of justice is to be institutionalized? What is the importance of individual rights compared to collective decisions? Finally, the third basic value conflict concern the stance society adopts towards nature. Is nature to be used simply as a reservoir of resources or should it be respected on its own right?

Goulet argues that "(t)he provision by a society of satisfactory conceptual, institutional, behavioural answers to these three questions is what constitutes authentic development" (Goulet, 2004: 8). There are no easy answers, simple blueprints and one-size-fits-all recipes in development. Economic growth is not a proper answer; globalization isn't either. Development ethics' first task is to raise awareness about the complexity of the development project, which is, as Goulet so eloquently put it, about the quest for good life.

\section{Conclusion}

Development is a never-ending project of humanity: improving the quality of life for everyone. As Goulet observed, even those post-developmentalist critiques who debunk the development as an essentially hegemonic project led by the rich countries and aiming at controlling the rest of the world, ultimately argue for something that is best to be called alternative development (Goulet, 2004). It is not the term that should be rejected - it is its content, objectives and nature that should be under scrutiny.

The chapter uses the ideas of Denis Goulet who argued that development is, first, an undeniably normative and value-laden concept, and second, that it is a multi-dimensional phenomenon. That is, development is about creating a better world, and this should include improvements not only in terms of welfare, but also of social conditions, political empowerment, the cultural foundations of self-esteem and ecological aspects. The chapter overviews the state of development in the era of globalization and argues that despite some of its achievements the current development model fails to meet important challenges, like the environmental one. However, this is not accidental: development led by globalization seems to be structurally unable to embody all the necessary social, cultural and environmental aspects. An ethical development certainly requires the transformation of global business and economic regulatory rules, but, more importantly, it also needs a complex social, political and institutional infrastructure that can ensure the translation of the different dimensions of development into decisions and practice.

\section{References}

Acemoglu, D., \& Robinson, J. (2012). Why nations fail: the origins of power, prosperity, and poverty. Crown Business. 
Anand, R. P. (2004). Common heritage of mankind: mutilation of an ideal. In Studies in International Law and History (pp. 180-196). Springer.

Anand, S., \& Ravallion, M. (1993). Human development in poor countries: on the role of private incomes and public services. The Journal of Economic Perspectives, 7(1), $133-150$.

Barber, J. P., \& Dickson, A. K. (1995). Justice and order in international relations: The global environment. Just Environments-Intergenerational, International and Inter-Species Issues.

Beitz, Ch. (1979). Political Theory and International Relations. Princeton: Princeton University Press.

Bernstein, S. (2002). Liberal environmentalism and global environmental governance. Global Environmental Politics, 2(3), 1-16.

Bhagwati, J. N. (1977). The new international economic order: the North-South debate. MIT Bicentennial Studies (USA).

Birdsall, N., \& Fukuyama, F. (2011). The Post-Washington Consensus. Foreign Affairs, 90(2), 45-53.

Boda, Z. (2015). TTIP: Good, Bad or Ugly?. V4 Revue, 26/02, http://visegradrevue.eu/ttipgood-bad-or-ugly/

Boxill, B. (1987). Global equality of opportunity and national integrity. Social Philosophy and Policy, 5(1), 143-68.

Brundtland, G., Khalid, M., Agnelli, S., Al-Athel, S., Chidzero, B., Fadika, L., ... others. (1987). Our Common Future: Report for the World Commission on Environment and Development, United Nations.

Daly, H. E., Cobb, J. B., \& Cobb, C. W. (1994). For the common good: Redirecting the economy toward community, the environment, and a sustainable future. Beacon Press.

Daly, H. E., \& Farley, J. (2011). Ecological economics: principles and applications. Island press.

Dreze, J., Sen, A. K., \& others. (1991). Hunger and public action. Oxford Clarendon.

Friedman, H. S. (2013). Causal inference and the Millennium Development Goals (MDGs): Assessing whether there was an acceleration in MDG development indicators following the MDG declaration. MPRA Paper No. 48793

Gasper, D. (2004). The ethics of development: from economism to human development. Edinburgh University Press.

Gilens, M., \& Page, B. I. (2014). Testing theories of American politics: Elites, interest groups, and average citizens. Perspectives on Politics, 12(3), 564-581.

Gore, C. (2010). The MDG paradigm, productive capacities and the future of poverty reduction. IDS Bulletin, 41(1), 70-79.

Goulet, D. (1989). Participation in development: New avenues. World Development, 17(2), $165-178$.

Goulet, D. (1995). Development ethics: a guide to theory and practice. Apex Pr.

Goulet, D. (2004). Is Sustainable Development Possible in a Globalized World? Humanomics, 20(1), 3-16.

Kalb, D. (2005). From flows to violence Politics and knowledge in the debates on globalization and empire. Anthropological Theory, 5(2), 176-204.

Love, J. L. (1980). Raul Prebisch and the origins of the doctrine of unequal exchange. Latin American Research Review, 15(3), 45-72.

Meadows, D. H. (1972). Club of Rome. The Limits to growth; a report for the Club of Rome's project on the predicament of mankind. Universe, New York.

Meadows, D., Randers, J., \& Meadows, D. (2004). Limits to growth: the 30-year update. Chelsea Green Publishing. 
Milanovic, B. (2011). Worlds apart: Measuring international and global inequality. Princeton University Press.

Nordhaus, W. D., \& Tobin, J. (1972). Is growth obsolete? In Economic Research: Retrospect and Prospect, Volume 5, Economic Growth (pp. 1-80). Nber.

Peet, R., \& Hartwick, E. (2015). Theories of development: Contentions, arguments, alternatives. Guilford Publications.

Piketty, T. (2014). Capital in the twenty-first century. Harvard University Press.

Rostow, W. W. (1959). The stages of economic growth. The Economic History Review, 12(1), $1-16$.

Sachs, W. (1997). Development Dictionary, The: A Guide to Knowledge as Power. Orient Blackswan.

Sen, A. (1981). Poverty and famines: an essay on entitlement and deprivation. Oxford University Press.

Sen, A. (1998). Mortality as an indicator of economic success and failure. The Economic Journal, 108(446), 1-25.

Sen, A., \& others. (1988). The concept of development. Handbook of Development Economics, 1, 9-26.

Sheppard, E., \& Leitner, H. (2010). Quo vadis neoliberalism? The remaking of global capitalist governance after the Washington Consensus. Geoforum, 41(2), 185-194.

Singer, P. (2004). One world: The ethics of globalization. Yale University Press.

Stiglitz, J. (2012). The price of inequality. Penguin UK.

Stiglitz, J. E., Sen, A., \& Fitoussi, J.-P. (2010). Mismeasuring our lives: Why GDP doesn't add up. The New Press.

Streeten, P., \& Burki, S. J. (1978). Basic needs: some issues. World Development, 6(3), 411421.

Uslaner, E. M. (2002). The moral foundations of trust. Cambridge University Press.

United Nations. (1962). The United Nations Development Decade: Proposals for Action. New York, UN.

Van Waeyenberge, E. (2006). From Washington to post-Washington Consensus: illusions of development.

Vandemoortele, J. (2011). The MDG story: intention denied. Development and Change, $42(1), 1-21$.

Wade, R. H. (2004). Is globalization reducing poverty and inequality? World Development, 32(4), 567-589.

Wilber, C. K. (2010). Economics and ethics. Palgrave Macmillan.

Wilkinson, R., \& Pickett, K. (2010). The spirit level. Why Equality Is Better for everyone. Penguin UK. 